International Journal of Social Sciences and Humanities
Available online at www.sciencescholar.us
Vol. 6 No. 1, April 2022, pages: 42-48
e-ISSN: 2550-7001, p-ISSN: 2550-701X
https://doi.org/10.53730/ijssh.v6n1.2955

\title{
Evaluation of Village Owned Enterprises (BUMDES) in Hunuth Village, Baguala District, Ambon City 2021
}

\author{
(C) CrossMark \\ Wahab Tuanaya ${ }^{a}$, Joana J. Tuhumury ${ }^{b}$, Marno Wance $^{c}$ \\ Manuscript submitted: 27 November 2021, Manuscript revised: 18 December 2021, Accepted for publication: 09 January 2022
}

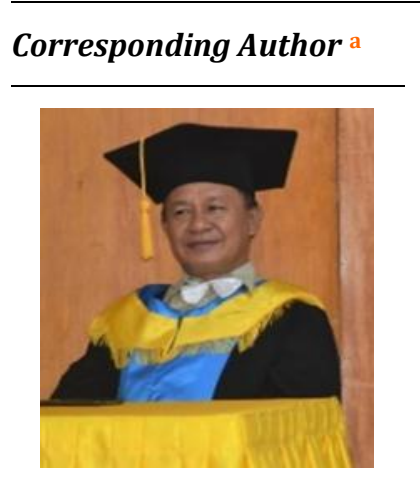

\section{Keywords}

BUMDES;

community

empowerment;

economic development;

public awareness;

village government;

\section{Abstract}

The Government of Hunut Village, Baguala Sub-district, Ambon City has built several business units to develop the local community's economy. The BUMDES is still experiencing problems, namely the limited working capital and the lack of public awareness to optimize the potential of natural resources and policies that have been made by the Village Government (Pemdes). These factors make BUMDES innovation less developed in Hunut Village so that it has not been able to run optimally. The research results are (1). The Bumdes of Hunuth/Durian Patah Village already have a turnover or income, but it is not significant yet to make the BUMDES revenue source the Original Village Income (PADes) of Hunuth. (2). BUMDES Hunuth is at level 3, which means BUMDES must conduct capacity-building training and marketing feasibility studies. With this approach, the author can provide a more detailed description and explanation of the results of the BUMDes evaluation research in Hunut Village, Baguala District, Ambon City, in 2021.

International Journal of Social Sciences and Humanities (C) 2022. This is an open access article under the CC BY-NC-ND license (https://creativecommons.org/licenses/by-nc-nd/4.0/).

\section{Contents}

Abstract

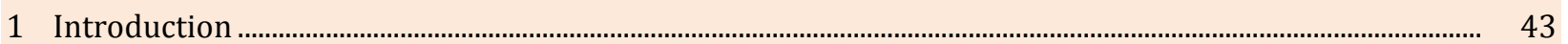

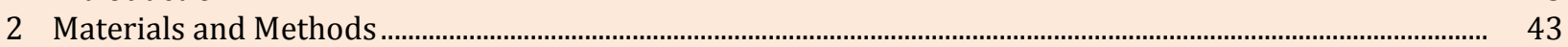

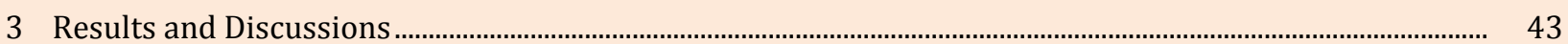

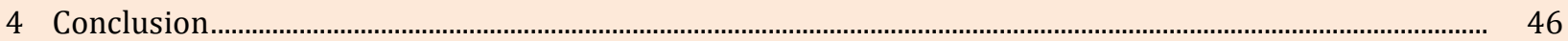

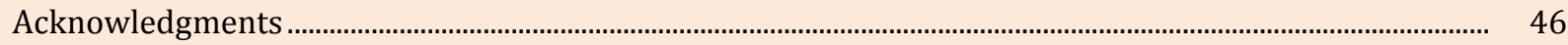

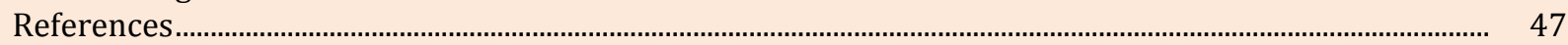

Biography of Authors ........................................................................................................................................................... 48

\footnotetext{
a Universitas Pattimura, Ambon, Indonesia

${ }^{b}$ Universitas Pattimura, Ambon, Indonesia

${ }^{c}$ Universitas Pattimura, Ambon, Indonesia
} 


\section{Introduction}

Village Owned Enterprises (BUMDes) is one of the strategic partners of the Village Government (Pemdes) in realizing economic development planning programs. The village government is required to develop and grow the village community's economy to provide for the community's needs in developing a business (Dewi, 2014). The formation of BUMDes is a way to take advantage of laws that give broad authority to village governments to innovate in village development, significantly improving the village economy and welfare for rural communities (Agunggunanto et al., 2016).

The establishment of BUMDes is a manifestation of the productive economic management of the village, which is carried out in a cooperative, participatory, emancipatory, transparent, accountable, sustainable manner. It is stated in Law Number 6 of 2014 that BUMDes can be established according to the needs and potential of the local village. What is meant by village needs and potentials are as follows; 1) Community needs, especially in meeting basic needs; 2) Availability of village resources that have not been used optimally; 3) Availability of human resources capable of managing business entities as assets that drive the economy of the community; 4) The existence of units which are economic activities of BUMDes community members are also established to suppress the development of a capitalist business system in rural areas which can result in disruption of the values of social life (Hampton, 2005; Dewi et al., 2005).

The function can be interpreted also refers to the process that will take place. The function is the use of a thing, while in terms, it is a functional concept that describes a person's task and is made as to the basis for a fundamental task that someone does. The Village Government (Pemdes) must be able to oversee the formation of BUMDes business groups and evaluate and monitor so that business groups can run well and obtain optimal income (La Suhu \& Wance, 2019).

\section{Materials and Methods}

The research method used in conducting quality descriptive research is to conduct an evaluation analysis of Hunuth Village Owned Enterprises (BUMDes) in 2021. According to Singarimbun \& Effendi (1995), through qualitative methods, researchers must be able to hear and see the sources directly and speak the truth (hence do not be influenced) about themselves (them) according to their respective perspectives (perspective truth). Sugiyono (2010), explains that: descriptive research method is a research method to analyze the status of human groups, study an object, condition, system of thought, or events in the present (Porter et al., 2016; Holliday, 2010; Ratislavová \& Ratislav, 2014; Antin et al., 2015; Morse, 2015; Punch, 2013). The research was conducted for one year; the researcher and the team conducted direct interviews with (1) the Village Secretary, (2). Head of the Hunuth Village Owned Enterprise. (3). BUMDes treasurer. (4). Hunuth Village Community. In addition, researchers and the team carried out a direct field observation process to see the progress of BUMDes efforts that have been carried out from 2016 to date.

\section{Results and Discussions}

BUMDes is a village-owned enterprise that has the function of optimizing the village's potential in improving community welfare. Mr. Mishanto, as the head of the village of Sabah Balau, said that BUMDes must exist in every village, as in government regulation number 39 of 2010 concerning Village-Owned Enterprises and the law of the Republic of Indonesia Number 6 of 2014 concerning villages that the village government formed BUMDes to utilize all potential economy, economic institutions, as well as the potential of natural resources and human resources in order to improve the welfare of the Village community. So based on the law, the establishment of the Hunuth Village BUMDes, which was formed in 2016, became a tool to develop the community's economy (Hunuth Village Secretary Interview Results, 2021).

Tuanaya, W., Tuhumury, J. J., \& Wance, M. (2022). Evaluation of village owned enterprises (BUMDES) in Hunuth Village, Baguala District, Ambon City 2021. International Journal of Social Sciences and Humanities, 6(1), 42-48. https://doi.org/10.53730/ijssh.v6n1.2955 
Although BUMDes is separate from the formal village governance structure, BUMDes do not exist exclusively. The policy for establishing BUMDes must go through village regulations prepared by the village head and the BPD.

Table 1

Development of BUMDES Hunuth

\begin{tabular}{llll}
\hline No & Bumdes Business Type & Year & Budget Amount \\
\hline 1 & BRI Link & 2018 & 150 Million \\
& & Sourced from the Village & \\
& & Fund & \\
& Food Catering & 2020 & $33,300,000$ \\
& & Village Fund Source & \\
& $\begin{array}{l}\text { Grocery Store } \\
\text { ATK Supply Unit (Tables and Chairs, } \\
\text { Laptops, Home Renovations, Business } \\
\text { Places }\end{array}$ & $\begin{array}{l}2021 \\
\text { Budget sources from the }\end{array}$ & \\
& Ministry of Villages & \\
\hline
\end{tabular}

Source: BUMDES Hunuth Treasurer, 2021

The Interview results with the BUMDes Management also explained that the BUMDes institution was unique. BUMDes is not a pure government effort, not a joint venture with the community, not a private business, and not a form of public and private partnership. According to the Chairman, he also added that the principle of BUMDes is not a government project in the village but as a form of village initiative and movement (Interview of Bumdes Management, 2021). The establishment of BUMDes in Hunuth village greatly helps village income because, through BUMDes, the management of village potential can be adequately mobilized. Such as economic empowerment as a BUMDes effort in improving community business.

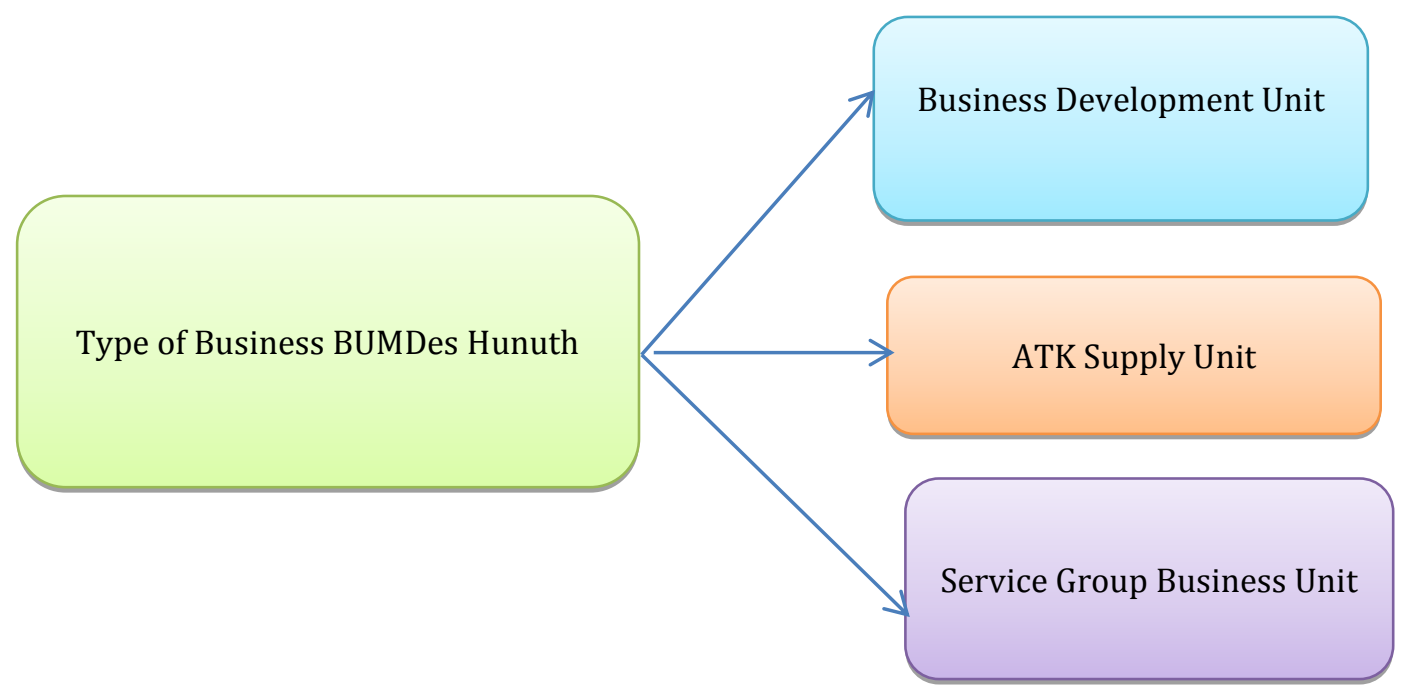

Figure 1. Bumdes Hunuth ecosystem

Source: BUMDES Hunuth Treasurer, 2021

Village funding from BUMDes is separate so that in the management of BUMDes, it stands alone but is still under the auspices of the village government. The formation of BUMDes is expected to be an effort to make Sabah Balau village a financially independent village so that it can help community capital. In terms of management, BUMDes stands alone, but income from each business unit managed by BUMDes goes into village funds, which are then channeled into building village facilities and community empowerment 
activities. However, the Hunuth BUMDES, which began to be established in 2018, has not become a source of income for the Hunuth village (Qin et al., 2020; Bromley, 1989; Anike et al., 2017). BUMDes only finances the operational needs of the management and finances employee expenses (Village Secretary Interview, 2021). BUMDes as a forum for business entities that oversee the community's small businesses to be more optimal. BUMDes Hunut in its management is also directly carried out by the local community. The business units managed by BUMDes that provide input into village finances are:

\section{Fisherman group business development unit}

At first, BUMDes members had difficulty running their businesses within a village business entity. The Village Unit Cooperative (KUD) was not developing, so a breakthrough was needed to convince the community. 2021) The BUMDes clusters in Hunuth Village are grouped as follows:

1) BUMDES typology; 1) Star 1- Already established but the business has not started; 2) Star 2-Business has been running but has not yet made a profit; 3) Binta 3-Business has made a profit, but it is not significant.

2) BUMDES Hunuth/Durian Broken; 1) Star4- Profit has reached $1 \mathrm{M}$; 2) 5 Stars-Making profit and impacting society.

Analysis of Bumdes evaluation indicators in Hunuth Village; Based on maturity (1 star to 5 stars), Based on stages (Starting, growing, advancing), Based on size ( turnover, size, and employees), and Based on the cluster (Social business, village tourism, savings and loans, trade, production). The presence of BUMDes can improve the economic level of the community. Although it is not yet fully developed, the Government assesses the enormous potential that BUMDes have shown. This effort can be a reference for the Government for future development. "This is called development from the village, so the community can directly optimize the village's potential. BUMDes Hunuth is in the category of already implementing the program but has not been able to become a source of Original Hunuth Village Revenue (APBDes) (Hunuth Village Secretary Interview, 2021).

\section{BRI link business}

BRI Link's business as a BUMDes Hunuth/Durian Patah business is one of the efforts carried out by the community as a source of community income. The management of BUMDes Hunut only cooperates with Bank Rakyat Indonesia (BRI) as the authorized party to provide access to governance and is then managed by the management of BUMDes Hunut. The method of business development and management and loans provided by BUMDes to the community funds from the village are the result of and collected from each business unit it owns; then there is also capital from BUMDes, the product of the community that makes the results divided in two. BUMDes manage both forms of savings by recirculating them to people in need. With savings, it is helpful to help the community not have trouble getting capital and the community to increase their economy. The nominal loan depends on the prospects of the business to be run. To be developed through small and medium enterprises (Wiber et al., 2009; Putterman, 1997).

\section{Community participation in the process of economic empowerment}

The indicator of the Hunut Village BUMDes in empowering the community's economy, which began in 2016, is the participation of the community itself. The community is the leading actor in increasing it to become the principal capital in improving community welfare and encouraging village independence. Therefore, community participation in the process of community economic empowerment through BUMDes includes: (1). Planning, namely, Community participation in planning, begins at the stage of community participation in forming BUMDes as a village autonomous body that represents the authority to mobilize community business activities. The following community participation in planning is the presence of the community in the socialization and planning of BUMDes activities (Lin \& Nugent 1995; Martini, 2020). Based on the results of observations in November 2019, the community supported and responded well to the establishment of

Tuanaya, W., Tuhumury, J. J., \& Wance, M. (2022). Evaluation of village owned enterprises (BUMDES) in Hunuth Village, Baguala District, Ambon City 2021. International Journal of Social Sciences and Humanities, 6(1), 42-48. https://doi.org/10.53730/ijssh.v6n1.2955 
BUMDes. (2). Implementation is the implementation carried out after the completion of planning and activities to implement community economic empowerment assisted by BUMDes management. The community participates in entrepreneurship training activities carried out by BUMDes, whose purpose is to empower local communities. (3). Monitoring and Evaluation is a necessary monitoring and evaluation activity, both from the Hunut/Durian Patah Village community outside BUMDes members and BUMDes members. This is explained according to the results of the interview, 2021 that it is true that the community must be involved in supervising all village activities, especially at this time, Village funds will be very high, if the community does not monitor it correctly, there are fears that the Village Apparatus will carry out irregularities (Gatto et al., 2017; Runge, 1986).

\section{Conclusion}

Based on the results of research and discussion, the conclusions of this study are in the form of points that answer the formulation of the problem in the previous chapter, namely about: a) Bumdes Hunuth/Durian Patah Village already has a turnover or income, but it is not significant yet to make the BUMDES revenue source as Hunuth Village Original Income (PADes); b) There are still Hunuth/Durian Patah BUMDES administrators who still have limited time in managing BUMDES optimally by dividing the time owned by BUMDES management; c) BUMDES Hunuth/Durian Patah still needs to map the production market as a management source for fisherman group units; d) BUMDES Hunuth is at level 3, which means BUMDES must conduct capacity-building training and marketing feasibility studies.

\section{Acknowledgments}

Our gratitude goes to Pattimura University for providing researchers with the opportunity to obtain Institutional Research Grants from the Faculty of Social and Political Sciences. The lecturer of the Department of Administrative Sciences has provided input and support so that this research can be completed. 


\section{References}

Agunggunanto, E. Y., Arianti, F., Kushartono, E. W., \& Darwanto, D. (2016). Pengembangan desa mandiri melalui pengelolaan badan usaha milik desa (BUMDes). Jurnal Dinamika Ekonomi \& Bisnis, 13(1).

Anike, H. O. O., Okafor, C. N., \& Udejinta, N. B. (2017). The role of public enterprises in economic development in Nigeria. International Research Journal of Management, IT and Social Sciences, 4(2), 179-189. Retrieved from https://sloap.org/journals/index.php/irjmis/article/view/459

Antin, T. M., Constantine, N. A., \& Hunt, G. (2015). Conflicting discourses in qualitative research: The search for divergent data within cases. Field Methods, 27(3), 211-222.

Bromley, D. W. (1989). Property relations and economic development: the other land reform. World Development, 17(6), 867-877. https://doi.org/10.1016/0305-750X(89)90008-9

Dewi, A. S. K. (2014). Peranan Badan Usaha Milik Desa (BUMDes) Sebagai Upaya Dalam Meningkatkan Pendapatan Asli Desa (PADes) Serta Menumbuhkan Perekonomian Desa. Journal of Rural and Development, 5(1).

Dewi, S., Belcher, B., \& Puntodewo, A. (2005). Village economic opportunity, forest dependence, and rural livelihoods in East Kalimantan, Indonesia. World Development, 33(9), 1419-1434. https://doi.org/10.1016/j.worlddev.2004.10.006

Gatto, M., Wollni, M., Asnawi, R., \& Qaim, M. (2017). Oil palm boom, contract farming, and rural economic development: Village-level evidence from Indonesia. World Development, 95, 127-140. https://doi.org/10.1016/j.worlddev.2017.02.013

Hampton, M. P. (2005). Heritage, local communities and economic development. Annals of tourism Research, 32(3), 735-759. https://doi.org/10.1016/j.annals.2004.10.010

Holliday, A. (2010). Analysing qualitative data. Continuum companion to research methods in applied linguistics, 98-110.

La Suhu, B., \& Wance, M. (2019). Pemberdayaan Masyarakat Petani Rumput Laut Di Kabupaten Halmahera Selatan (Studi Desa Mano Kecamatan Obi Selatan). JOURNAL OF GOVERNMENT (Kajian Manajemen Pemerintahan dan Otonomi Daerah), 4(2), 156-172.

Lin, J. Y., \& Nugent, J. B. (1995). Institutions and economic development. Handbook of development economics, 3, 2301-2370. https://doi.org/10.1016/S1573-4471(05)80010-5

Martini, N. K. A. (2020). Community participation in Blangsinga tourism village development. International Research Journal of Management, IT and Social Sciences, 7(3), 91-97. https://doi.org/10.21744/irjmis.v7n3.922

Morse, J. M. (2015). Critical analysis of strategies for determining rigor in qualitative inquiry. Qualitative health research, 25(9), 1212-1222.

Porter, W. W., Graham, C. R., Bodily, R. G., \& Sandberg, D. S. (2016). A qualitative analysis of institutional drivers and barriers to blended learning adoption in higher education. The internet and Higher education, 28, 17-27. https://doi.org/10.1016/j.iheduc.2015.08.003

Punch, K. F. (2013). Introduction to social research: Quantitative and qualitative approaches. sage.

Putterman, L. (1997). On the past and future of China's township and village-owned enterprises. World Development, 25(10), 1639-1655. https://doi.org/10.1016/S0305-750X(97)00060-0

Qin, X., Li, Y., Lu, Z., \& Pan, W. (2020). What makes better village economic development in traditional agricultural areas of China? Evidence from 338 villages. Habitat International, 106, 102286. https://doi.org/10.1016/j.habitatint.2020.102286

Ratislavová, K., \& Ratislav, J. (2014). Asynchronous email interview as a qualitative research method in the humanities. Human Affairs, 24(4), 452-460.

Runge, C. F. (1986). Common property and collective action in economic development. World development, 14(5), 623-635. https://doi.org/10.1016/0305-750X(86)90128-2

Singarimbun, M., \& Effendi, S. (1995). Metode Penelitian Survei, Edisi Revisi, PT. Pustaka LP3ES, Jakarta.

Sugiyono, D. (2010). Memahami penelitian kualitatif.

Wiber, M., Charles, A., Kearney, J., \& Berkes, F. (2009). Enhancing community empowerment through $\begin{array}{llll}\text { participatory } & \text { fisheries } & \text { research. Marine } & \text { 172-179. }\end{array}$ https://doi.org/10.1016/j.marpol.2008.05.009

Tuanaya, W., Tuhumury, J. J., \& Wance, M. (2022). Evaluation of village owned enterprises (BUMDES) in Hunuth Village, Baguala District, Ambon City 2021. International Journal of Social Sciences and Humanities, 6(1), 42-48. https://doi.org/10.53730/ijssh.v6n1.2955 


\section{Biography of Authors}

\begin{tabular}{|l|l||}
\hline Wahab Tuanaya \\
He is a Lecturer in Governmental Sciences, Faculty of Social and Political Sciences \\
at Universitas Pattimura, Ambon, Indonesia. \\
Email: wahab.tuanaya@fisip.unpattiac.id
\end{tabular}

